\title{
The Efficacy of Naïve versus Modified Mesenchymal Stem Cells in Improving Muscle Function in Duchenne Muscular Dystrophy: A Systematic Review
}

\author{
Oscar Yuan-Jie Shen ${ }^{1}\left(\mathbb{D}\right.$, Yi-Fan Chen ${ }^{2,3}\left[\right.$, Hong-Tao Xu ${ }^{4}$, and Chien-Wei Lee ${ }^{5,6, *(\mathbb{C})}$ \\ 1 Faculty of Medicine, The Chinese University of Hong Kong, Hong Kong 999077, China; \\ oscar.shen11@gmail.com \\ 2 The Ph.D. Program for Translational Medicine, College of Medical Science and Technology, \\ Taipei Medical University, Taipei 11031, Taiwan; evan.yifan@tmu.edu.tw \\ 3 Master Program in Clinical Genomics and Proteomics, School of Pharmacy, Taipei Medical University, \\ Taipei 11031, Taiwan \\ 4 Department of Orthopaedics and Traumatology, Faculty of Medicine, Prince of Wales Hospital, \\ The Chinese University of Hong Kong, Hong Kong 999077, China; xhtsmed@gmail.com \\ 5 Institute for Tissue Engineering and Regenerative Medicine, The Chinese University of Hong Kong, \\ Hong Kong 999077, China \\ 6 School of Biomedical Sciences, Faculty of Medicine, The Chinese University of Hong Kong, \\ Hong Kong 999077, China \\ * Correspondence: icehikki@gmail.com or chienweilee@cuhk.edu.hk; Tel.: +852-39430645
}

Citation: Shen, O.Y.-J.; Chen, Y.-F.; Xu, H.-T.; Lee, C.-W. The Efficacy of Naïve versus Modified Mesenchymal Stem Cells in Improving Muscle Function in Duchenne Muscular Dystrophy: A Systematic Review. Biomedicines 2021, 9, 1097. https:// doi.org/10.3390/biomedicines9091097

Academic Editor: Andrea Farini

Received: 22 July 2021

Accepted: 23 August 2021

Published: 27 August 2021

Publisher's Note: MDPI stays neutral with regard to jurisdictional claims in published maps and institutional affiliations.

Copyright: (c) 2021 by the authors. Licensee MDPI, Basel, Switzerland. This article is an open access article distributed under the terms and conditions of the Creative Commons Attribution (CC BY) license (https:// creativecommons.org/licenses/by/ $4.0 /)$.
Abstract: As one of the most common genetic conditions, Duchenne muscular dystrophy (DMD) is a fatal disease caused by a recessive mutation resulting in muscle weakness in both voluntary and involuntary muscles and, eventually, in death because of cardiovascular failure. Currently, there is no pharmacologically curative treatment of DMD, but there is evidence supporting that mesenchymal stem cells (MSCs) are a novel solution for treating DMD. This systematic review focused on elucidating the therapeutic efficacy of MSCs on the DMD in vivo model. A key issue of previous studies was the material-choice, naïve MSCs or modified MSCs; modified MSCs are activated by culture methods or genetic modification. In summary, MSCs seem to improve pulmonary and cardiac functions and thereby improve survival regardless of them being naïve or modified. The improved function of distal skeletal muscles was observed only with primed MSCs treatment but not naïve MSCs. While MSCs can provide significant benefits to DMD mouse models, there is little to no data on the results in human patients. Due to the limited number of human studies, the differences in study design, and the insufficient understanding of mechanisms of action, more rigorous comparative trials are needed to elucidate which types of MSCs and modifications have optimal therapeutic potential.

Keywords: mesenchymal stem cells Duchenne muscular dystrophy; muscle function; fibrosis; regenerative cell therapy; contraction-induced injury

\section{Introduction}

DMD is an X-linked recessive pediatric disorder and is one of the most frequent genetic conditions, affecting approximately 1 in 3500 male births worldwide [1]. The dystrophin mutation at locus Xp21 results in a sarcolemma lacking dystrophin, which is a vital structural link between the extracellular matrix and the cytoskeletal proteins [2]. The absence of dystrophin destabilizes the sarcolemma-cytoskeleton architecture, causing myofibers to be highly susceptible to contraction-associated mechanical stress. Subsequent myocyte death results in the inflammation and fibrosis of muscle [2].

Patients with Duchenne's are diagnosed at the average age of 5, and more than $90 \%$ are in wheelchairs by age 15 [3]. Dystrophin is demonstrated to be involved in brain 
development, and patients with DMD are more likely to have conditions such as attention deficit hyperactivity disorder, autism, and seizure disorders [4]. Although the life is extended by supportive interventions, a substantial economic burden remains, not only for DMD patients but also the whole healthcare system, with the US household burden in 2012 estimated to be $\$ 58,440$ to $\$ 71,900$ and a conservative societal burden estimated between $\$ 80,120$ and $\$ 120,910$ per year per patient, which does not include mortality-likely a major cost component because of the low life expectancy associated with DMD [5]. Due to improvements in supportive interventions, patients can now survive into their 40s, generally succumbing to respiratory or cardiac failure [6]. Skeletal muscle structure and function are abnormal in individuals with heart failure, which contributes to deconditioning and exercise intolerance. Heart failure patients also exhibit attenuated peripheral vascular responses to exercise and reduced respiratory muscle endurance. Respiratory failure appears to occur secondary to heart failure rather than directly due to skeletal muscle weakness. Most strategies, however, such as corticosteroids, although slightly improve prognosis, have numerous adverse effects and are by no means curative for DMD [7].

Since there is no definitive cure for DMD, current therapeutics are palliative and focus on managing symptoms and slowing disease progression [8]. Corticosteroids are the most used medication for DMD, as they reduce inflammation in the muscles, help the heart and lungs remain stronger for longer, and reduce the chance of severe scoliosis [9]. Unfortunately, they are also associated with numerous adverse effects, including weight gain, osteopenia, growth impairment, and behavioral disturbances [10]. Myostatin inhibition is currently being evaluated in clinical trials for treating DMD, as myostatin normally limits muscle growth. Inhibiting myostatin would therefore increase muscle mass in patients and may delay the effects of muscle degeneration, but some preliminary studies have shown that direct treatment with myostatin inhibitors failed to improve outcomes [11]. As muscle fibers are damaged in DMD, fibrosis occurs and replaces muscle with fat and connective tissue, preventing muscles from working normally [12]. Clinical trials are being conducted to determine whether medications targeting the fibrosis process can preserve muscle integrity. There are also some therapies being investigated for specific mutations causing DMD, including exon-skipping and nonsense mutation suppression that increase the expression of dystrophin [13-15].

Stem cells are an attractive therapy for DMD because they could theoretically (1) replace damaged myofibers, (2) increase the expression of dystrophin, and (3) modulate the inflammatory effects, which directly results in fibrosis and muscular dysfunction [16]. MSC properties, including immunomodulation, non-tumorgenicity, no ethic issues, enhanced regeneration, in vitro expansion ability, and even anti-senescence ability, make them promising in the treatment of DMD [17]. In this study, we focus on the clinical significance of MSC treatment; therefore, direct muscle function measurements were emphasized rather than secondary outcomes such as protein expression, muscle fibrosis, and creatine kinase levels. A systemic understanding of the use of MSCs in DMD would provide insights into new treatment methods that can be investigated and elucidate the benefits of the methods that have already been tested. With advances in stem cell therapy, patients with DMD will hopefully have even longer lifespans and there will be a better quality of life for patients and caregivers.

\section{Materials and Methods}

The Preferred Reporting Items for Systematic Reviews and Meta-Analyses (PRISMA) statement was used for this article. Meanwhile, the Cochrane handbook was selected as the guidelines for the study protocol.

\subsection{Search Strategy and Study Selection}

We searched PubMed and Web of Science to select studies. We searched for MeSH terms and other related turning relating to "Mesenchymal Stem Cells"—which includes mesenchymal stromal cells and mesenchymal progenitors-and "Duchenne Muscular 
Dystrophy" in the title and abstract field. The details of selected search terms and search procedures are available in the Supplementary Material (Supplementary File). Additional studies were also located by searching papers referenced in listed articles. Studies identified through the search were combined, and any duplicates were removed. Then, titles and abstracts were screened before the in-detail review of full-text articles. Of the remaining studies, we examined their full full-text articles for inclusion in the study.

The search resulted in 258 studies across both data bases with a total of 66 duplicates. Our inclusion criteria were: full-text available, written in English, published in the last 20 years, contained original data, and related to MSCs and DMD. Our exclusion criteria were: text not in English, full-text not available, no direct measurement of muscle function, case reports, case series, reviews, articles, letters, and chapters. The criteria are illustrated in Table 1. All articles were screened by reading their titles and abstracts first. A total of 109 studies were removed because they did not fulfill the inclusion criteria or they met the exclusion criteria. The 53 remaining studies had their full text reviewed, and 44 of them were excluded after reviewing for various reasons-the most common being not having muscle function as a measured outcome. The 11 remaining studies underwent secondary full-text review and were confirmed as fitting the inclusion criteria. The flow chart of the selected studies selection process—based on the PRISMA 2009 Flow Diagram-is shown in Figure 1.

Table 1. Inclusion and exclusion criteria for studies.

\begin{tabular}{cc}
\hline Inclusion Criteria & Exclusion Criteria \\
\hline Full-text available & Full text not available \\
Written in English & Text not in English \\
Articles published in the last 20 years & No direct measurement of muscle function \\
Articles containing original data & Case reports, case series, reviews, letters, chapters \\
$\begin{array}{c}\text { Studies related to mesenchymal stem cells } \\
\text { and Duchenne muscular dystrophy }\end{array}$ & \\
\hline
\end{tabular}

\subsection{Data Extraction}

All relevant data were extracted including: author information, published journal, year of publication, cell source, subject type, cell harvesting and processing method, injection method, and measurement methodology. Measurement methodology included tests to assess muscle function, PCRs, immunohistochemistry, western blots, and histological analysis. The details of results extraction consisted of variable/control group descriptions, measured effects on muscle function, and conclusions.

\subsection{Methodological Quality Assessment}

Methodological assessment is an essential procedure to exclude articles that could potentially have a higher degree of bias. The 11 identified studies were reviewed, and all included data were analyzed based on study heterogeneity and methodological quality. Due to the heterogeneity of the nature and measurement across studies, a meta-analysis could not be performed. The selected studies were assessed with the quality scoring system proposed by Slim et al. called the Methodological Item for Non-Randomized Studies (MINORS) tool [18]. The MINORS tool gives each article 0-2 points on up to 12 aspects, with a maximum score of 16 for non-comparative studies and a maximum score of 24 for comparative studies. Detailed scoring can be found in the Supplementary Material (Supplementary File). 


\section{PRISMA 2009 Flow Diagram}
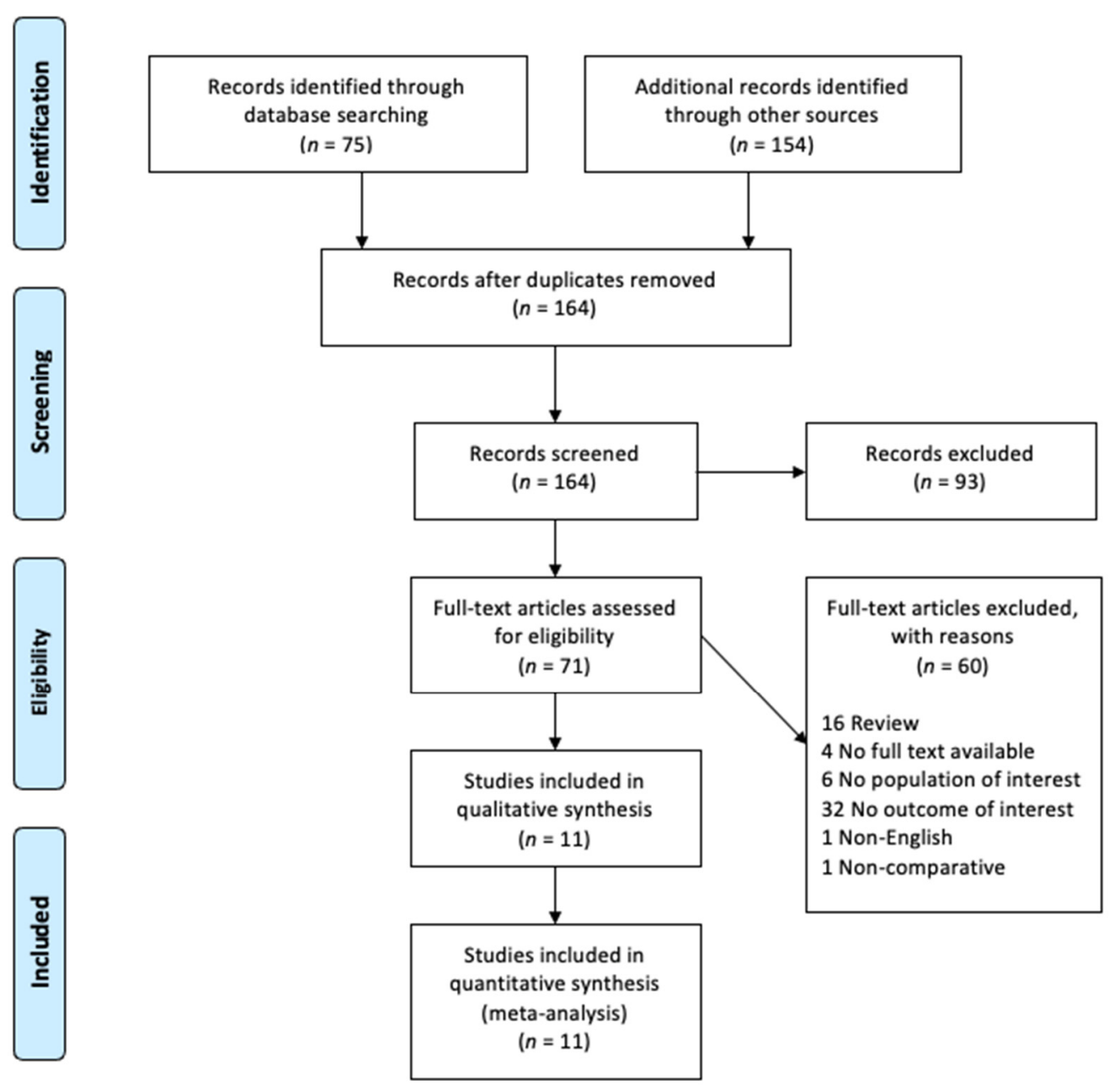

Figure 1. PRISMA Flow Diagram for the study selection process.

\section{Results}

\subsection{Study of Methodology Quality Assessment}

According to the MINORS tool, all of the studies included had an extremely high score, with all comparative studies receiving a score of 22 out of a possible 24 and the only non-comparative study receiving a score of 13 out of 16 . The scores are listed in Table 2 . The high scores are likely since all the comparative studies used mice, which have established progenies that mimic Duchenne muscular dystrophy. Due to the well-controlled nature of all the studies, their scores were all remarkably high. None of the studies scored points regarding the prospective calculation of the study size needed for statistical significance. Using information on the size of the detectable difference of interest with a calculation of $95 \%$ confidence interval, according to the expected incidence of the outcome event, and information about the level for statistical significance and estimates of power when comparing the outcomes, an appropriate study size can be estimated to achieve statistical significance in outcomes. 
Table 2. MINORS score of selected studies.

\begin{tabular}{cc}
\hline Study & MINORS Score \\
\hline Dai A. et al. (2018) [19] & 13 of 16 \\
Siemionow M. et al. (2019) [20] & 22 of 24 \\
Pang R. et al. (2014) [21] & 22 of 24 \\
Valadares M. et al. (2014) [22] & 22 of 24 \\
Esper G. et al. (2015) [23] & 22 of 24 \\
Siemionow M. et al. (2021) [24] & 22 of 24 \\
Nitahara-Kashara et al. (2021) [25] & 22 of 24 \\
Geng J et al. (2009) [26] & 22 of 24 \\
Li Z. et al. (2011) [27] & 22 of 24 \\
Ruehle M. et al. (2018) [28] & 22 of 24 \\
Rousseau J. et al. (2010) [29] & 22 of 24 \\
\hline
\end{tabular}

\subsection{Study of Characteristics}

Detailed characteristics of selected studies can be found in Table 3. Of the selected 11 studies, one was published in 2009, one in 2010, one in 2011, one in 2014, one in 2015, two in 2018, one in 2019, and two in 2021. Only one was non-comparative and was also the only study done on human patients with Duchenne Muscular Dystrophy (Dai et al. [19]). Nine of the studies experimented on $x$-linked muscular dystrophy (mdx) mice, which are considered equivalent to Duchenne muscular dystrophy, with six using MSCs from humans (Siemionow M et al. (2019) [20], Pang et al. [21], Valadares et al. [22], Esper et al. [23], Siemionow M et al. (2021) [24], and Nitahara-Kashara et al. [25]), three using cells from Sprague-Dawley rats (Geng et al. [26], Li et al. [27], and Nitahara-Kashara et al. [25]), and three studies using cells from utrophin/dystrophin double knockout (dko) mice. Mdx are the most widely used animal model for DMD research overall. Their lifespans are relatively normal compared to those of individuals with DMD. Skeletal muscle changes only begin occurring between 3-6 weeks, with severe dystrophic phenotypes such as muscle wasting, scoliosis, and heart failure only occurring at 15 months or older [30]. Dko mice are distinct from $\mathrm{mdx}$ mice as $\mathrm{mdx}$ still have functional dystrophin. Mdx mice are hypothesized to regenerate skeletal muscle to some extent by replacing dystrophin with utrophin, resulting in a much milder disease state with lifespans comparable to those of wild-type mice. Dko mice have a much more severe form of the disease that mimics the progression of DMD and may be considered a superior model for DMD [31].

One study used MSCs from healthy beagle dogs. Six studies involved modified MSCs. MSCs were considered modified if they were processed or modified in any way beyond purely isolating or inducing differentiation in the cells, including adjuvant therapies. Siemionov et al. (2019) [20] created fused cells using a combination of MSCs from mdx mice and myoblasts from wild type and mdx mice. Ruehle et al. [28] used single-cell MSCs and aggregated MSCs using 3D culture. Geng et al. induced the differentiation of bone marrow MSCs and primed them with or without myostatin antibodies. Esper et al. used false aquapuncture with MSCs and true aquapuncture with MSCs. Siemionov et al. (2021) [24] also used fused cells using human MSCs and myoblasts. Nitahara-Kashara et al. used adenoviruses to transduce IL-10 vectors into some MSCs. Two studies investigated cardiac function using echocardiography and/or electromyography (Dai et al. [19], Siemionov et al. (2019) [20]), and one study investigated respiratory function using spirometry (Dai et al.). Four studies investigated muscle function using the rotarod performance test as a method (Pang et al. [21], Valadares et al. [22], Geng et al. [26], Li et al. [27]), three studies used electrodes to measure muscle function (Siemionov et al. (2021) [24], Ruehle et al. [28], Rousseau et al. [29]), and two studies used a wire test to measure motor function (Esper et al. [23], Siemionov et al. (2021) [24]). All of the studies also measured other surrogates in conjunction with immunohistochemical and/or histological analysis to confirm muscle function. 
Table 3. Characteristics of selected studies.

\begin{tabular}{|c|c|c|c|c|c|c|c|c|c|c|c|}
\hline Author & Journal & Year & $\begin{array}{l}\text { Compartive/Non- } \\
\text { Comparative }\end{array}$ & Cell Source & $\begin{array}{c}\text { Subject Type; } \\
\text { aGe at } \\
\text { Treatment }\end{array}$ & $\begin{array}{l}\text { Modified/ } \\
\text { Unmodified }\end{array}$ & $\begin{array}{l}\text { Cell Harvesting and } \\
\text { Processing }\end{array}$ & Injection Method & $\begin{array}{c}\text { Number of } \\
\text { Independent } \\
\text { Measurements }\end{array}$ & $\begin{array}{l}\text { Measurement } \\
\text { Methodology }\end{array}$ & Reference \\
\hline $\begin{array}{l}\text { Dai A. et al. } \\
\text { (2018) [19] }\end{array}$ & $\begin{array}{l}\text { Degenerative } \\
\text { Neurologi- } \\
\text { cal and } \\
\text { Neuromus- } \\
\text { cular } \\
\text { Disease }\end{array}$ & 2018 & $\begin{array}{l}\text { Non- } \\
\text { comparative }\end{array}$ & Human & $\begin{array}{l}\text { Human; } \\
7 \text { to } 14 \text { years old }\end{array}$ & Unmodified & $\begin{array}{l}\text { Umbilical cords were } \\
\text { obtained from consenting } \\
\text { patients delivering } \\
\text { full-term infants by } \\
\text { Caesarian section }\end{array}$ & $\begin{array}{l}2 \times 10^{6} \text { cells } / \mathrm{kg} / \text { dose } \\
\text { injections every } 2 \text { weeks for } \\
4 \text { months, alternating } \\
\text { between systemic } \\
\text { intra-arterial administration } \\
\text { and local intramuscular } \\
\text { injections }\end{array}$ & 5 & $\begin{array}{l}\text { Electromyography; } \\
\text { Spirometry; } \\
\text { Echocardiography; } \\
\text { Immunohistochemical } \\
\text { analysis; Fluorescent in } \\
\text { situ hybridization }\end{array}$ & [19] \\
\hline $\begin{array}{l}\text { Siemionow M. } \\
\text { et al. (2019) } \\
\text { [20] }\end{array}$ & $\begin{array}{l}\text { Stem Cell } \\
\text { Reviews } \\
\text { and Reports }\end{array}$ & 2019 & Comparative & $\begin{array}{l}\text { mdx mice; } \\
\text { snj (wild } \\
\text { type) mice }\end{array}$ & $\begin{array}{l}\text { Mdx mice; } \\
8 \text { weeks old }\end{array}$ & Modified & $\begin{array}{l}\text { Myoblasts were harvested } \\
\text { from the hind limb } \\
\text { muscles of both wild type } \\
\text { and mdx mice. MSCs } \\
\text { were harvested from the } \\
\text { femur and tibia of mdx } \\
\text { mice only. The fusion } \\
\text { cells MBwt/MBmdx and } \\
\text { MBwt/MSCmdx were } \\
\text { created. Some MBwt, } \\
\text { MBmdx and MSCmdx } \\
\text { were saved }\end{array}$ & $\begin{array}{l}60 \mu \mathrm{L} \text { systemic-intraosseous } \\
\text { saline injections to femoral } \\
\text { bone }\end{array}$ & 3 & $\begin{array}{l}\text { Histological and } \\
\text { immunofluorescence of } \\
\text { cardiac muscle cross } \\
\text { sections; } \\
\text { Echocardiography } \\
\text { Assessment }\end{array}$ & [20] \\
\hline $\begin{array}{l}\text { Pang R. et al. } \\
\text { (2014) [21] }\end{array}$ & Cytotherapy & 2014 & Comparative & Human & $\begin{array}{l}\text { Mdx mice; } \\
6 \text { weeks old }\end{array}$ & Unmodified & $\begin{array}{l}\text { To induce myogenic } \\
\text { differentiation, cells were } \\
\text { cultured in myogenic } \\
\text { differentiation medium } \\
\text { (Lonza, Basel, } \\
\text { Switzerland) for } 10 \text { days. }\end{array}$ & $\begin{array}{l}\text { Two million ELSCs or MSCs } \\
\text { in } 500 \mu \mathrm{L} \text { of saline were } \\
\text { injected into each mouse } \\
\text { through the tail vein. For } \\
\text { control, } 500 \mu \mathrm{L} \text { of saline was } \\
\text { injected through the tail } \\
\text { vein. }\end{array}$ & 9 & $\begin{array}{l}\text { Analysis of motor } \\
\text { function via traction, } \\
\text { rotating rod, and } \\
\text { running wheel tests; } \\
\text { CK activity via } \\
\text { NADPH fluorescence } \\
\text { kit followed by } \\
\text { spectrophotometry; } \\
\text { Immunohistochemistry; } \\
\text { Western blotting; } \\
\text { RT-PCR; Histological } \\
\text { analysis }\end{array}$ & [21] \\
\hline $\begin{array}{l}\text { Valadares M. } \\
\text { et al. (2014) } \\
\text { [22] }\end{array}$ & $\begin{array}{l}\text { Stem Cell } \\
\text { Reviews } \\
\text { and Reports }\end{array}$ & 2014 & Comparative & Human & $\begin{array}{l}\text { Mdx mice; } \\
7 \text { weeks old }\end{array}$ & Unmodified & $\begin{array}{l}\text { Four tissue specimens } \\
\text { from a 46-year-old } \\
\text { healthy female donor, } \\
\text { namely: adipose tissue, } \\
\text { muscle, fallopian tubes } \\
\text { and endometrium were } \\
\text { obtained from total } \\
\text { hysterectomy procedures. } \\
\text { All pericyte populations } \\
\text { were confirmed to have at } \\
\text { least } 75 \% \text { purity after } \\
\text { sorting. }\end{array}$ & $\begin{array}{l}\text { Injected intraperitonially } \\
\text { with } 1 \text { million viable cells } \\
\text { (or vehicle), once a week, for } \\
\text { a total of } 8 \text { weeks, without } \\
\text { any immunosuppression. } \\
\text { These seven groups were } \\
\text { comprised by animals } \\
\text { receiving either: vehicle, } \\
\text { fibroblasts, myoblasts, } \\
\text { pericytes (endometrium), } \\
\text { pericytes (fallopian tubes), } \\
\text { pericytes (adipose tissue) } \\
\text { and pericytes (muscle). }\end{array}$ & 9 & $\begin{array}{l}\text { Analysis of motor } \\
\text { function via } \\
\text { ambulation test, grip } \\
\text { test, and rotarod; } \\
\text { Myogenic } \\
\text { differentiation; qPCR; } \\
\text { PCR; Western blot; } \\
\text { Immunohistochemistry; } \\
\text { Histological analysis }\end{array}$ & [22] \\
\hline
\end{tabular}


Table 3. Cont.

\begin{tabular}{|c|c|c|c|c|c|c|c|c|c|c|c|}
\hline $\begin{array}{l}\text { Esper G. et al. } \\
\text { (2015) [23] }\end{array}$ & $\begin{array}{l}\text { Evidence- } \\
\text { Based } \\
\text { Comple- } \\
\text { mentary } \\
\text { and } \\
\text { Alternative } \\
\text { Medicine }\end{array}$ & 2015 & Comparative & Human & $\begin{array}{l}\text { Mdx mice; } \\
4 \text { to } 6 \text { weeks old }\end{array}$ & Modified & $\begin{array}{l}\text { MSCs derived from } \\
\text { deciduous teeth were } \\
\text { obtained using a modified } \\
\text { Miura's protocol with } \\
\text { collagenase type I for } \\
\text { pulp digestion }\end{array}$ & $\begin{array}{l}1 \times 10^{4} \text { cells suspended in } \\
20 \text { microliters saline injected } \\
\text { every three weeks, totaling } \\
\text { three injections via acupoint } \\
\text { at Bladder } 47,49 \text {, and } 52 .\end{array}$ & 3 & $\begin{array}{l}\text { Analysis of motor } \\
\text { function via wire test; } \\
\text { CK-NAC; Histological } \\
\text { analysis }\end{array}$ & [23] \\
\hline $\begin{array}{l}\text { Siemionow M. } \\
\text { et al. (2021) } \\
\text { [24] }\end{array}$ & $\begin{array}{l}\text { Stem Cells } \\
\text { and Devel- } \\
\text { opment }\end{array}$ & 2021 & Comparative & Human & $\begin{array}{l}\text { Mdx mice; } \\
6 \text { to } 8 \text { weeks old }\end{array}$ & Modified & $\begin{array}{l}\text { Allogenic human } \\
\text { myoblasts and normal } \\
\text { human bone } \\
\text { marrow-derived MSCs } \\
\text { underwent fusion exvivo } \\
\text { using polyethylene. Cells } \\
\text { presenting double } \\
\text { PKH26/PKH67 staining } \\
\text { were sorted through } \\
\text { fluoresence-activated cell } \\
\text { sorting and used for } \\
\text { in vitro and invivo } \\
\text { analysis }\end{array}$ & $\begin{array}{l}0.25 \times 10^{6} \text { fused cells or } \\
0.5 \times 10^{6} \text { of unfused cells } \\
\text { were suspended in } 60 \\
\text { microliters of Dulbecco's } \\
\text { phosphate-buffered saline. } \\
\text { This volume was delivered } \\
\text { into the left gastrocnemius } \\
\text { of each mouse through six } \\
\text { injections }\end{array}$ & 6 & $\begin{array}{l}\text { Analysis of motor } \\
\text { function via wire } \\
\text { hanging and grip } \\
\text { strength test, in situ } \\
\text { muscle force test, and } \\
\text { ex vivo muscle force } \\
\text { test; Histological } \\
\text { analysis; } \\
\text { Immunofluoresence } \\
\text { analysis }\end{array}$ & [24] \\
\hline $\begin{array}{l}\text { Nitahara- } \\
\text { Kashara et al. } \\
\text { (2021) [25] }\end{array}$ & $\begin{array}{l}\text { Stem Cell } \\
\text { Research \& } \\
\text { Therapy }\end{array}$ & 2021 & Comparative & $\begin{array}{l}\text { Sprague- } \\
\text { Dawley } \\
\text { rats, } \\
\text { Human, } \\
\text { Beagle dogs }\end{array}$ & $\begin{array}{l}\text { NOD/SCID } \\
\text { mice, Beagle } \\
\text { dogs, Canine } \\
\text { X-linked } \\
\text { muscular } \\
\text { dystrophy } \\
\text { model (CXMDj); } \\
3 \text { to } 52 \text { months } \\
\text { old }\end{array}$ & Modified & $\begin{array}{l}\text { MSCs isolated from } \\
\text { Sprague-Dalwey rat bone } \\
\text { marrow were transduced } \\
\text { with a } \\
\text { luciferase-expressing } \\
\text { retroviral vector. Canine } \\
\text { CD271 + MSCs were also } \\
\text { transduced with a } \\
\text { luciferase-expressing } \\
\text { retroviral vector as well as } \\
\text { an enhnaced green } \\
\text { fluorescent protein (eGFP) } \\
\text { or MyoD-expressing } \\
\text { adenoviral vector. MSCs } \\
\text { or human dental pulp } \\
\text { stem cells (hDPSCs) were } \\
\text { transduced with } \\
\text { adeno-associated virus } \\
\text { (AAV)/eGFP or control } \\
\text { AAV1/IL-10 vectors }\end{array}$ & $\begin{array}{l}5.0-10.0 \times 10^{6} \\
\text { luciferase-expressing rat } \\
\text { MSCs were injected } \\
\text { intramuscularly into the } \\
\text { right or lift hindlimb muscle } \\
\text { of NOD/SCID mice } \\
\text { pretreated with cardiotoxin } \\
1 \text { day before treatment. } \\
1.0 \times 10^{7} \text { of both } \\
\text { eGFP-MSCs and } \\
\text { IL-10-MSCs were injected } \\
\text { into the right and left } \\
\text { hindlimb, respectively. } \\
\text { AAV1/IL-10 transduced } \\
\text { Luc-CD271 }+ \text { MSCs } \\
\left(2.4-2.7 \times 10^{7} \text { cells } / 2 \mathrm{~mL}\right) \\
\text { were injected into the } \\
\text { muscles of healthy beagles } \\
\text { on days } 0 \text { and } 50 \text { without } \\
\text { immunosupressants. The } \\
\text { tibialis anterior muscles } \\
\text { were pretreated by injecting } \\
10 \mathrm{nmol} / \mathrm{kg} \text { of cardiotoxin. } \\
\mathrm{hDPSCC} \text { or AAV1/IL- } 10 \\
\text { transduced hDPSCs } \\
\left(4.0 \times 10^{6} \text { cells } / \mathrm{mL} / \mathrm{kg}\right. \\
\text { body weight at a rate of } \\
1 \mathrm{~mL} / \mathrm{min}) \text { was adminstered } \\
\text { intravenously into CXMDj } \\
\text { using nine injections at two } \\
\text { week intervals. }\end{array}$ & 13 & $\begin{array}{l}\text { Analysis of motor } \\
\text { function via 15-m } \\
\text { running time and } \\
\text { counts of spontaneous } \\
\text { locomotor activity; } \\
\text { Creatinine kinase; } \\
\text { Alanine } \\
\text { aminotransferase; } \\
\text { Aspartate } \\
\text { aminotransferase; } \\
\text { blood urea nitrogen; } \\
\text { Histological analysis; } \\
\text { Immunohistochemical } \\
\text { analysis; ELISA; } \\
\text { Luciferase reporter } \\
\text { assays; Biodistribution } \\
\text { of MSCs; } \\
\text { Cytokine/cytokine } \\
\text { array; MRI }\end{array}$ & [25] \\
\hline
\end{tabular}


Table 3. Cont.

\begin{tabular}{|c|c|c|c|c|c|c|c|c|c|c|c|}
\hline $\begin{array}{l}\text { Geng J et al. } \\
\text { (2009) [26] }\end{array}$ & Cytotherapy & 2009 & Comparative & $\begin{array}{l}\text { Sprague- } \\
\text { Dawley } \\
\text { rats }\end{array}$ & $\begin{array}{l}\text { Mdx mice; } \\
7 \text { to } 9 \text { weeks old }\end{array}$ & Modified & $\begin{array}{l}\text { Femur and tibia bone } \\
\text { marrow mesenchymal } \\
\text { stem cells were incubated } \\
\text { in complete medium } \\
\text { containing } 10 \mu \mathrm{M} \text { 5-AzaC } \\
\text { for } 24 \mathrm{~h} \text { to induce } \\
\text { differentiation, and } \\
\text { incubated with or without } \\
10-100 \mu \mathrm{g} / \mathrm{mL} \text { polyclonal } \\
\text { anti-myostatin Ab in } \\
\text { differentiation medium }\end{array}$ & $\begin{array}{l}1.2 \times 10^{7} \mathrm{MSC} \text { of the } \\
\text { mixture were infused per } \\
\text { mouse through the tail vein. } \\
\text { One day before } \\
\text { transplantation, mdx mice } \\
\text { in the Ab transplantation } \\
\text { group were injected } \\
\text { intraperitoneally with } \\
\text { anti-myostatin antibody ( } 6 \\
\mathrm{mg} / \mathrm{kg} / \text { week). }\end{array}$ & 5 & $\begin{array}{l}\text { Immunofluorescence } \\
\text { analysis; RT-PCR; } \\
\text { Motor function via } \\
\text { Rota-rod; CK-NAC; } \\
\text { Western blot }\end{array}$ & [26] \\
\hline $\begin{array}{l}\text { Li Z. et al. } \\
\text { (2011) [27] }\end{array}$ & Cytotherapy & 2011 & Comparative & $\begin{array}{l}\text { Sprague- } \\
\text { Dawley } \\
\text { rats }\end{array}$ & $\begin{array}{l}\text { Mdx mice; } \\
6 \text { weeks old }\end{array}$ & Unmodified & $\begin{array}{l}\text { Bone marrow MSCs were } \\
\text { extracted from the femurs } \\
\text { and tibias of male rats. }\end{array}$ & $\begin{array}{l}\text { Cell density was adjusted to } \\
1 \times 10^{7} / \mathrm{mL} \text {. A volume of } \\
0.5 \mathrm{~mL} \text { MSC suspended in } \\
\text { PBS was administered via } \\
\text { tail vein injection into each } \\
\text { experimental dko mouse, } \\
\text { and matched controls were } \\
\text { administered equivalent } \\
\text { injections of PBS. }\end{array}$ & 5 & $\begin{array}{l}\text { Analysis of motor } \\
\text { function via traction, } \\
\text { rotating rod, and } \\
\text { running wheel tests; } \\
\text { Histological analysis; } \\
\text { Detection of grafted } \\
\text { cells }\end{array}$ & [27] \\
\hline $\begin{array}{l}\text { Ruehle M. } \\
\text { et al. (2018) } \\
\text { [28] }\end{array}$ & $\begin{array}{l}\text { Journal of } \\
\text { Tissue } \\
\text { Engineering } \\
\text { and Regen- } \\
\text { erative } \\
\text { Medicine }\end{array}$ & 2018 & Comparative & $\begin{array}{l}\text { Wild type } \\
\text { C57BL } / 6 \\
\text { mice }\end{array}$ & $\begin{array}{l}\text { Mdx mice; } \\
12 \text { weeks old }\end{array}$ & Modified & $\begin{array}{l}\text { Mesenchymal stem cells } \\
\text { were lentivirally } \\
\text { GFP-labelled to confirm } \\
\text { multipotency and } \\
\text { proliferative capacity. } \\
\text { Some cells were formed } \\
\text { into aggregates by } \\
\text { centrifuging and } \\
\text { incubating overnight to } \\
\text { form spheroidal } \\
\text { aggregates }\end{array}$ & $\begin{array}{l}\text { Mice received local } 100 \mu \mathrm{L} \\
\text { injections containing MSC } \\
\text { aggregates, MSC single cells, } \\
\text { or saline. } 5 \times 10^{5} \mathrm{MSC} s \\
\text { were in each injection except } \\
\text { for saline }\end{array}$ & 4 & $\begin{array}{l}\text { Peak isometric torque } \\
\text { via servomotor and } \\
\text { Pt-Ir needle electrodes; } \\
\text { Histological analysis; } \\
\text { Cell } \\
\text { immunomodulatory } \\
\text { factor quantification }\end{array}$ & [28] \\
\hline $\begin{array}{l}\text { Rousseau J. } \\
\text { et al. (2010) } \\
\text { [29] }\end{array}$ & $\begin{array}{l}\text { Cell Trans- } \\
\text { plantation }\end{array}$ & 2010 & Comparative & $\begin{array}{l}\text { Normal } \\
\text { C57BL/10 J } \\
\text { and } \\
\text { C57BL } / 10 \mathrm{~J} \\
\mathrm{mdx} / \mathrm{mdx} \\
\text { mice }\end{array}$ & $\begin{array}{l}\text { Mdx mice; } \\
12 \text { month old }\end{array}$ & Unmodified & $\begin{array}{l}\text { Muscles dissected from } \\
\text { arms and legs were cut } \\
\text { into small fragments and } \\
\text { digested with collagenase } \\
\text { and dispase. After } 48 \text { hrs } \\
\text { in culture, Muscle } \\
\text { precursor cells were } \\
\text { frozen in nitrogen until } \\
\text { transplantation. }\end{array}$ & $\begin{array}{l}\text { A total of } 1.5 \text { million cells } \\
\text { were injected in several sites } \\
\text { throughout each of the left } \\
\text { and right extensor } \\
\text { digitorum longus }\end{array}$ & 2 & $\begin{array}{l}\text { Analysis of motor } \\
\text { function via electrode } \\
\text { stimulation in organ } \\
\text { bath; } \\
\text { Immunohistochemistry }\end{array}$ & [29] \\
\hline
\end{tabular}

${ }^{*}$ Measurement methodologies considered to directly measure muscle function are bolded. 


\subsection{Cell Management and Injection}

Siemionow et al. (2019) [20] harvested myoblasts from the hind limb muscles of both wild type and mdx mice. MSCs were harvested from the femur and tibia of mdx mice only. The fusion cells MBwt/MBmdx and MBwt/MSCmdx were created. Then, $0.25 \times 10^{6}$ fused cells were given via $60 \mu \mathrm{L}$ systemic-intraosseous saline injections into the femoral bone of mdx mice. Dai et al. [19] obtained Wharton-Jelly MSCs from consenting patients delivering full-term infants by Caesarian sections and injected $2 \times 10^{6}$ cells $/ \mathrm{kg} /$ dose every 2 weeks for 4 months, alternating between systemic intra-arterial administration and local intramuscular injections in patients with DMD. Ruehle et al. [28] used MSCs from C57BL/ 6 mice and formed MSCs into aggregates by centrifuging and incubating overnight to form spheroidal aggregates. The mice received $100 \mu \mathrm{L}$ injections containing MSC aggregates, MSC single cells, or saline. Furthermore, $5 \times 10^{5}$ MSCs were in the injection each mouse received except for the saline group. Geng et al. [26] isolated bone marrow MSCs from the femur and tibia of Sprague-Dawley rats and induced myogenic differentiation with or without $10-100 \mu \mathrm{g} / \mathrm{mL}$ polyclonal anti-myostatin antibody. Then, $1.2 \times 10^{7} \mathrm{MSCs}$ of the mixture were infused per mouse through the tail vein. One day before transplantation, mdx mice in the $\mathrm{Ab}$ transplantation group were injected intraperitoneally with anti-myostatin antibodies ( $6 \mathrm{mg} / \mathrm{kg} /$ week). Li et al. [27] extracted bone marrow MSCs from the femurs and tibias of male Sprague-Dawley rats. The cell density was adjusted to $1 \times 10^{7}$ cells $/ \mathrm{mL}$. A volume of $0.5 \mathrm{~mL}$ MSCs suspended in PBS was administered via tail vein injection into each experimental utrophin/dystrophin-deficient double knockout mouse, and matched controls were administered equivalent injections of PBS. Pang et al. [21] induced the myogenic differentiation of embryonic-like stem cells (ELSCs) and MSCs by culturing them in myogenic differentiation medium (Lonza Group, Basel, Switzerland) for 10 days. Then, $2 \times 10^{6}$ ELSCs or MSCs in $500 \mu \mathrm{L}$ of saline were injected into each mouse through the tail vein. For controls, $500 \mu \mathrm{L}$ of saline was injected through the tail vein. Valadares et al. [22] isolated fibroblasts, myoblasts, endometrial pericytes, fallopian tube pericytes, adipose pericytes, and muscle pericytes from a single 46-year-old healthy female donor. Then, $1 \times 10^{6}$ cells (or vehicle) were injected intraperitoneally into the mice once a week for 8 weeks without any immunosuppression. Esper et al. [23] isolated MSCs from human deciduous for pulp digestion. After trypsinization, cells were washed twice and $1 \times 10^{4}$ cells were suspended in $20 \mu \mathrm{L}$ of saline and injected once every three weeks. Rousseau et al. [29] dissected muscles from the arms and legs of wild type and mdx mice and digested with collagenase and dispase to isolate muscle progenitor cells. The left and right extensor digitorum longus were injected in several sites with a total of $1.5 \times 10^{6}$ cells injected per muscle. Siemionow et al. (2021) [24] used fused human myoblasts and MSCs $\left(\mathrm{MB}^{\mathrm{N}} / \mathrm{MSC}^{\mathrm{N}}\right.$ ) and injected a total of $0.25 \times 10^{6}$ of these fused cells into the left gastrocnemius of the mice with six injections. Nitahara-Kashara et al. [25] isolated MSCs from Sprague-Dawley rat bone marrow and transduced them with a luciferase-expressing retroviral vector, creating luciferase-expressing MSCs (Luc-MSCs). Canine CD271 + MSCs were transduced with a luciferase-expressing retroviral followed by transduction with enhanced green fluorescent proteins (eGFPs) or MyoD-expressing adenoviral vectors. All MSCs and human dental pulp stem cells (hDPSCs) were transduced with AAV1/eGFP or control AAV1/IL-10 vectors. Then, 5.0-10.0 $\times 10^{6}$ luciferase-expressing rat MSCs were injected intramuscularly into the right or left hindlimb muscle of NOD/SCID mice pretreated with cardiotoxin 1 day before treatment. Then, $1.0 \times 10^{7}$ of both eGFP-MSCs and IL-10-MSCs were injected into the right and left hindlimb, respectively. Five days before treatment, healthy beagle dogs had cardiotoxin injected into the tibialis anterior. A total of $2.4-2.7 \times 10^{7}$ cells $/ 2 \mathrm{~mL}$ of AAV1/IL10-transduced Luc-CD271 + MSCs were injected into their muscles on days 0 and 50 without immunosuppression. hDPSCs or AAV1/IL-10-transduced hDPSCs $\left(4.0 \times 10^{6}\right.$ cells $/ \mathrm{mL} / \mathrm{kg}$ body weight at a rate of $1 \mathrm{~mL} / \mathrm{min}$ ) were administered intravenously into the canine muscular dystrophy model $\left(\mathrm{CXMD}_{\mathrm{J}}\right)$. 


\subsection{Measurement Instruments}

For classifying results, the studies used a variety of measurement instruments, including histological analysis, immunohistochemistry, echocardiography, electromyography, spirometry, fluorescent in situ hybridization, servomotor, electrodes, cell immunomodulatory factor quantification, RT-PCR, rotarod tests, nicotinamide adenine dinucleotide phosphate fluorescence kit followed by spectrophotometry to detect creatine kinase, Western blot, and PCR. The detailed measurement instruments used in each study are listed in Table 3.

\subsection{Experimental Variables and Controls}

In Siemionow et al.'s (2019) study [20], the experimental variables were fused cells created with myoblasts from wild type and $\mathrm{mdx}$ mice $\left(\mathrm{MB}^{\mathrm{wt}} / \mathrm{MB}^{\mathrm{mdx}}\right)$, fused cells created with myoblasts from wild type mice and MSCs from mdx mice (MSC ${ }^{m d x}$ ), and the simultaneous injection of wild type myoblasts and $\mathrm{mdx}$ myoblasts $\left(\mathrm{MB}^{\mathrm{wt}}+\mathrm{MB}^{\mathrm{mdx}}\right)$ and wild type myoblasts and $\mathrm{mdx}$ MSCs $\left(\mathrm{MB}^{\mathrm{wt}}+\mathrm{MSC}^{\mathrm{mdx}}\right.$ ) into $\mathrm{mdx}$ mice. Wild type mice with no treatment and mdx mice with saline injection served as controls. In Dai et al.'s [19] study, they did not perform any controls and used human Wharton jelly-derived MSCs to treat human patients with DMD. Ruehle et al. [28] used mouse-derived single-cell MSCs and aggregated MSCs to treat mdx mice without myotoxic injury and wild type mice with myotoxic injury and compared it to both types of mice receiving saline injections. Geng et al. [26] compared rat bone marrow MSC transplant + / - myostatin antibody into mdx mice to $\mathrm{mdx}$ mice that received no transplant. Li et al. compared rat MSC transplantation into double knockout (dko) mice to wild type mice with PBS injections and dko mice with only PBS injections (no MSCs). Pang et al. [21] performed embryonic stem cell and MSC injection into dko with saline injection only in dko mice as a control. Valadares et al. [22] injected a variety of cell types (fibroblast, myoblast, endometrial pericyte, fallopian tube pericyte, adipose pericyte, and adipose pericyte) into dko mice and used vehicle (HBSS) injection only in dko mice as a control. Esper et al. [23] were interested in the therapeutic effects of aquapuncture and used false aquapuncture with stem cells from human exfoliated deciduous teeth (SHED), true aquapuncture with saline, and true aquapuncture with SHED in mice with no aquapuncture as a control. Rousseau et al. [29] transplanted mdx mice with muscle progenitor cells derived from normal $10 \mathrm{~J}$ mice and $\mathrm{mdx}$ mice. They compared them to $\mathrm{mdx}$ mice with no treatment and $\mathrm{mdx}$ mice injected with cardiotoxin. Siemionow et al. (2021) [24] injected fused $\mathrm{MB}^{\mathrm{N}} / \mathrm{MSC}^{\mathrm{N}}$ cells and unfused $\mathrm{MB}^{\mathrm{N}}+\mathrm{MSC}^{\mathrm{N}}$ cells into mdx mice, comparing them with each other and vehicle injections as the control. Nitahara-Kashara et al. [25] compared mice transplanted with IL-10 MSCs with those transplanted with eGFP-MSCs, healthy beagles transplanted with cardiotoxin and IL-10-Luc-CD271 + MSCs with healthy beagles transplanted with cardiotoxin and MyoD-Luc-CD271 + MSCs, and $\mathrm{CXMD}_{\text {J }}$ transplanted with IL-10-hDPSCs with those transplanted with normal hDPSCs. The details are summarized in Table 4. 
Table 4. Experimental variables, results, and conclusions of selected studies.

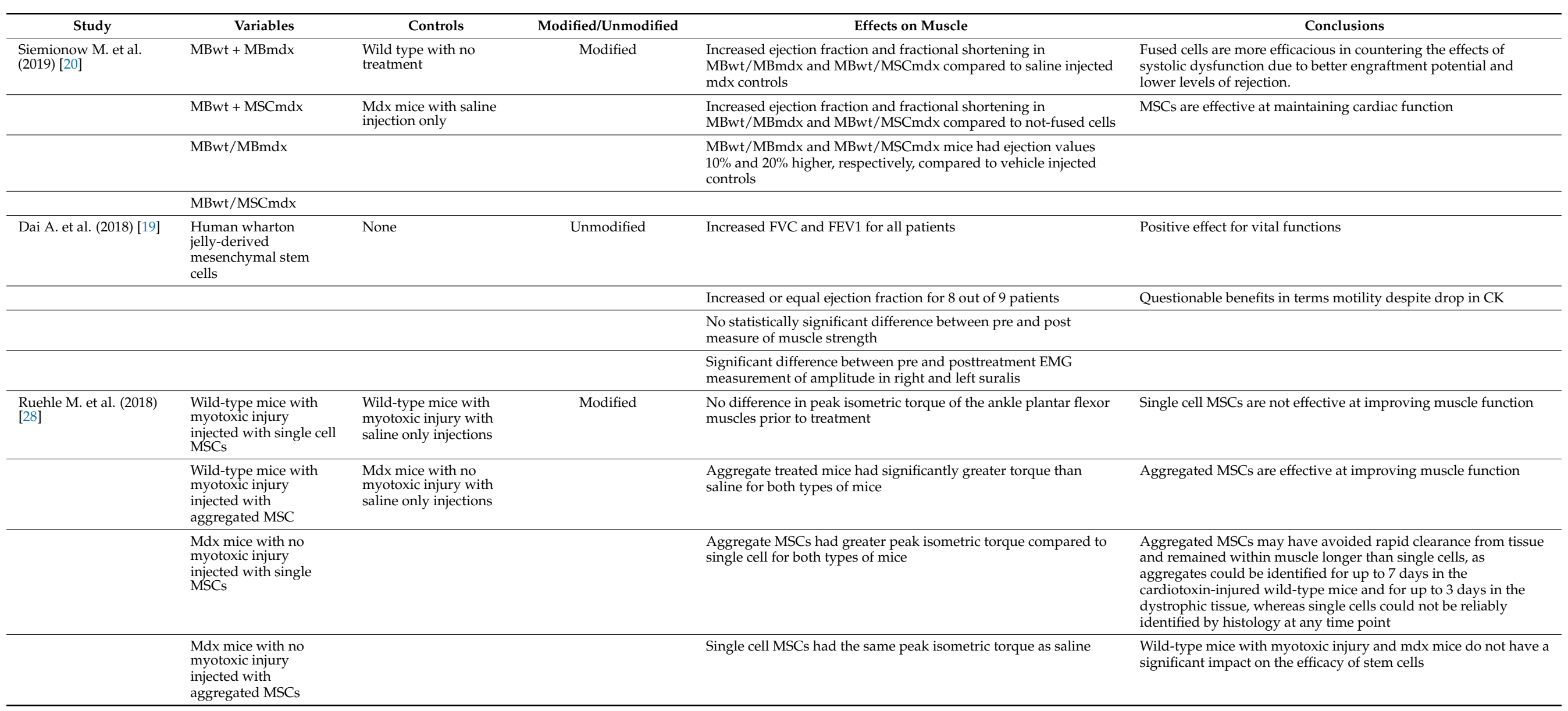


Table 4. Cont

\begin{tabular}{|c|c|c|c|c|c|}
\hline Geng J et al. (2009) [26] & $\begin{array}{l}\text { Rat bone marrow } \\
\text { mesenchymal stem } \\
\text { cells (transplant) }\end{array}$ & No transplant & Modified & No difference between the no transplant and transplant group & MSCs alone are ineffective at improving muscle function \\
\hline & $\begin{array}{l}\text { Rat bone marrow } \\
\text { mesenchymal stem } \\
\text { cells + myostatin } \\
\text { antibody (Ab } \\
\text { transplant) }\end{array}$ & & & $\begin{array}{l}\text { Ab transplant group greatly improved motor function compared } \\
\text { to no transplant and transplant }\end{array}$ & $\begin{array}{l}\text { Inhibition of myostatin improves the MSC ability to improve } \\
\text { muscle function }\end{array}$ \\
\hline \multirow[t]{3}{*}{ Li Z. et al. (2011) [27] } & MSC transplantation & $\begin{array}{l}\text { PBS injection only wild } \\
\text { type }\end{array}$ & Unmodified & $\begin{array}{l}\text { Until } 15 \text { weeks after transplantation, no abnormalities were } \\
\text { observed in either the diet or behavior of transplanted mice }\end{array}$ & $\begin{array}{l}\text { MSCs provide significant improvements in motor function and } \\
\text { lifespan, although it is still significantly worse than normal mice }\end{array}$ \\
\hline & & $\begin{array}{l}\text { PBS injection only dko } \\
\text { mice }\end{array}$ & & $\begin{array}{l}\text { The median lifespan of normal control mice was significantly } \\
\text { higher than both other groups, but the median lifespan of the } \\
\text { transplantation group ( } 35 \mathrm{wks}) \text { was significantly higher than that } \\
\text { of the control mice ( } 22 \mathrm{wks})\end{array}$ & \\
\hline & & & & $\begin{array}{l}\text { All motor function tests showed significant improvement in } \\
\text { experimental mice compared to control groups. Normal control } \\
\text { mice performed significantly better than experimental mice, } \\
\text { though }\end{array}$ & \\
\hline \multirow[t]{2}{*}{$\begin{array}{l}\text { Pang R. et al. (2014) } \\
\text { [21] }\end{array}$} & ELSC injection & $\begin{array}{l}\text { Saline injection only } \\
\text { dko mice }\end{array}$ & Unmodified & $\begin{array}{l}\text { ELSC transplanted mice had significantly improved motor } \\
\text { function in all tests compared with dko mice transplanted with } \\
\text { MSCs or saline }\end{array}$ & $\begin{array}{l}\text { ELSCs were superior to MSCs by every metric, even though } \\
\text { MSCs were already significantly better than saline only injections. } \\
\text { The increased myogenic differentiation of ELSCs may be } \\
\text { responsible for this discrepancy }\end{array}$ \\
\hline & MSC injection & & & & \\
\hline \multirow[t]{6}{*}{$\begin{array}{l}\text { Valadares M. et al. } \\
\text { (2014) [22] }\end{array}$} & Fibroblast injection & $\begin{array}{l}\text { Vehicle (HBSS) } \\
\text { injection only in dko } \\
\text { mice }\end{array}$ & Unmodified & $\begin{array}{l}\text { Endometrial-derived pericytes showed significant effects related } \\
\text { to the age of the onset of injections. The younger the dko mice } \\
\text { started being treated, the better the survival. This observation } \\
\text { was not seen in any other treated groups }\end{array}$ & $\begin{array}{l}\text { All cells were ineffective at engrafting and providing significant } \\
\text { benefits to muscle function }\end{array}$ \\
\hline & Myoblast injection & & & $\begin{array}{l}\text { Only adipose derived pericytes increased life expectancy in } \mathrm{mdx} \\
\text { mice }\end{array}$ & \\
\hline & $\begin{array}{l}\text { Endometrial pericyte } \\
\text { injection }\end{array}$ & & & $\begin{array}{l}\text { Despite improved survival in adipose pericyte injected mice, } \\
\text { none of the physical tests revealed differences between the groups }\end{array}$ & \\
\hline & $\begin{array}{l}\text { Fallopian tube pericyte } \\
\text { injection }\end{array}$ & & & $\begin{array}{l}\text { No human cells were found in any analyzed tissues and no } \\
\text { difference in the HE stained sections of the gastrocnemius muscle }\end{array}$ & \\
\hline & $\begin{array}{l}\text { Adipose pericyte } \\
\text { injection }\end{array}$ & & & $\begin{array}{l}\text { No in vitro myogenic potential in pericytes derived from any } \\
\text { tissue source was found }\end{array}$ & \\
\hline & $\begin{array}{l}\text { Muscle pericyte } \\
\text { injection }\end{array}$ & & & & \\
\hline \multirow[t]{3}{*}{$\begin{array}{l}\text { Esper G. et al. (2015) } \\
\text { [23] }\end{array}$} & $\begin{array}{l}\text { False aquapuncture } \\
\text { with SHEDs }\end{array}$ & No aquapuncture & Modified & $\begin{array}{l}\text { Strength improvement in mice with SHED/true acupoints and } \\
\text { only slight improvement with saline/true acupoints and } \\
\text { SHED/false acupoints compared to controls }\end{array}$ & $\begin{array}{l}\text { Acupuncture and MSCs each have a beneficial effect in muscle } \\
\text { force that can complement each other }\end{array}$ \\
\hline & $\begin{array}{l}\text { True aquapuncture } \\
\text { with saline }\end{array}$ & & & $\begin{array}{l}\text { Although creatine kinase decreased in all treatments, only } \\
\text { SHED/true acupoint was able to improve force }\end{array}$ & \\
\hline & $\begin{array}{l}\text { True aquapuncture } \\
\text { with SHEDs }\end{array}$ & & & & \\
\hline
\end{tabular}


Table 4. Cont

\begin{tabular}{|c|c|c|c|c|c|}
\hline $\begin{array}{l}\text { Rousseau J. et al. (2010) } \\
\text { [29] }\end{array}$ & $\begin{array}{l}\text { Mdx mice transplanted } \\
\text { with } 10 \mathrm{~J} \text { MPCs }\end{array}$ & No treatment $\mathrm{mdx}$ mice & Unmodified & $\begin{array}{l}\text { There was no significant force difference observed between the } \\
\text { different groups, even those injected with cardiotoxin }\end{array}$ & $\begin{array}{l}\text { Replacing dystrophin can increase resistance to exercise and } \\
\text { contraction-induced injury but not sufficiently enoigh to increase } \\
\text { the strength of the muscle }\end{array}$ \\
\hline & $\begin{array}{l}\text { Mdx mice transplanted } \\
\text { with mdx MPCs }\end{array}$ & $\begin{array}{l}\text { Mdx mice injected with } \\
\text { cardiotoxin only }\end{array}$ & & $\begin{array}{l}\text { Mdx mice with } 10 \mathrm{~J} \mathrm{MPCs} \text { transplanted increased muscle } \\
\text { protection against eccentric contractions }\end{array}$ & \\
\hline $\begin{array}{l}\text { Siemionow M. et al. } \\
\text { (2021) [24] }\end{array}$ & $\begin{array}{l}\text { Not-fused MB and } \\
\text { MSC }\end{array}$ & & & & \\
\hline \multirow[t]{5}{*}{$\begin{array}{l}\text { Nitahara-Kashara et al. } \\
\text { (2021) [25] }\end{array}$} & $\begin{array}{l}\text { Mice transplanted with } \\
\text { IL-10 MSCs }\end{array}$ & $\begin{array}{l}\text { Mice transplanted with } \\
\text { GFP-MSCs }\end{array}$ & Modified & $\begin{array}{l}\text { Muscle function was not measured specifically in mice, but IL-10 } \\
\text { expressing MSCs had significantly more cell survival and were } \\
\text { more effective at enhancing post-transplantation retention. } \\
\text { Il-10-Luc-MSCs were retained for more than } 67 \text { days after } \\
\text { transplantation }\end{array}$ & $\begin{array}{l}\text { Higher retention in early stages exerts a significant effect on } \\
\text { long-term engraftment }\end{array}$ \\
\hline & $\begin{array}{l}\text { Beagles transplanted } \\
\text { with cardiotoxin and } \\
\text { IL-10-Luc-CD271 + } \\
\text { MSCs }\end{array}$ & $\begin{array}{l}\text { Beagles transplanted } \\
\text { with cardiotoxin and } \\
\text { MyoD-Luc-CD271 + } \\
\text { MSCs }\end{array}$ & & $\begin{array}{l}\text { Lucisferase activity, which correlates to the number of MSCs, } \\
\text { tended to be higher in IL-10-Luc-CD271 + MSC. IL-10 levels in } \\
\text { IL-10-Luc-CD271+ MSC treated tibialis anterior muscles } \\
\text { increased, while those in MYoD-Luc-CD271 +MSC-treated } \\
\text { muscles did not. }\end{array}$ & $\begin{array}{l}\text { IL-10 expressing CD271+ MSCs could survive long term and } \\
\text { engraft after intramuscular regeneration }\end{array}$ \\
\hline & $\begin{array}{l}\text { CXMDj transplanted } \\
\text { with AAV1/IL-10- } \\
\text { tranduced } \\
\text { hDPSCs }\end{array}$ & $\begin{array}{l}\text { CXMDj transplanted } \\
\text { with hDPSCs }\end{array}$ & & $\begin{array}{l}\text { Significantly higher torque was found in IL-10-hDPSC-treated } \\
\text { CXMDj than in control CXMDj, which had similar values to } \\
\text { hDPSC-treated CXMDj. hDPSC and IL-10-hDPSC-treated CXMDj } \\
\text { maintained a 15-m running speed and were active at } 3 \text { to } 12 \\
\text { months of age. Only IL-10-hDPSC was effective at reducing CK } \\
\text { levels and lactic acid before and after exercise }\end{array}$ & $\begin{array}{l}\text { Only IL-10-hDPSCs exert a protective effect against dystrophic } \\
\text { damage caused by exercise }\end{array}$ \\
\hline & & & & $\begin{array}{l}\text { IL-10-hDPSCs were only detected in the TA muscles and not in } \\
\text { other organs. Dystrophin expression was undetectable in the } \\
\text { muscle tissues of hDPSC-treated CXMDj }\end{array}$ & \\
\hline & & & & $\begin{array}{l}\text { Il-10-hDPSCs decreased inflammation and necrotic/edematous } \\
\text { lesions and increased the weight and area of muscles. hDPSCs } \\
\text { significantly limited the infiltration of nuclei, indicating a midler } \\
\text { phenotype }\end{array}$ & \\
\hline
\end{tabular}




\subsection{Laboratory Effects and Proposed Mechanisms}

Studies involving modified MSCs are marked with an asterisk (*).

\subsubsection{MSCs Improved Life Expectancy and Limb Function}

All studies were able to find some benefit in MSCs regardless of their methodology. Valadares et al.'s [22] results showed the least benefits from MSCs, as the only benefit found was an increased lifespan in mice treated with adipose-derived pericytes, and there is no factor that explains this finding. Three studies (Dai et al. [19], Valadares et al. [22], Li et al. [27]) measured both life expectancy —or its substitutes (cardiac and/or pulmonary function) - and limb function. Dai et al. [19] found that MSCs improved functional vital capacity (FVC) and forced expiration volume in one second (FEV1) on spirometry and improved equal ejection fraction on echocardiography, but there was no significant difference in muscle strength on electromyography. Li et al. [27] were able to increase lifespan by over $50 \%$, although still less than half of the lifespan of normal control mice. Locomotor function was greatly improved. Valadares et al. [22] found increased lifespan in mice treated with adipose-derived pericytes and found no improved muscle function in any other groups. Siemionow et al.'s (2019)* [20] study was the only one to measure cardiac function using echocardiography, and it found significant improvements in ejection fraction and fractional shortening. The remaining seven studies (Pang et al. [21], Esper et al. ${ }^{*}$ [23], Siemionow et al. $(2021)^{*}$ [24], Nitahara-Kashara et al.* [25], Geng et al. ${ }^{*}$ [26], Ruehle et al. ${ }^{*}$ [28], Rousseau et al. [29]) only measured limb function, and all of them were able to find improvements.

Two studies (Dai et al. [19], Valadares et al. [22]) failed to show increased skeletal muscle function, but did find benefits to survival. Dai et al. [19] used human Wharton jelly-derived MSCs and found that there was no significant difference in muscle strength measured using a Powertrak HandHeld Dynamometer despite a significant increase in the amplitude measured via electromyography of the right and left soleus when injected with Wharton jelly-derived MSCs compared to controls. There was an increase in the dystrophin measured through immunohistochemistry. Valadares et al. [22] increased life expectancy with adipose-derived pericytes, but there was no improvement in muscle function in $\mathrm{mdx}$ mice.

\subsubsection{MSC Induced Myogenic Differentiation Is an Important Factor in Improving} Outcomes

Four of the studies (Siemionow et al. (2019)* [20], Pang et al. [21], and Siemionow et al. $(2021)^{*}$ [24], Geng et al.* [26]) showed that the ability of cells to differentiate was important in improving muscle function. Siemionow et al. (2019)* [20] demonstrated this, as fused myoblasts from mdx and wild type mice had increased ejection fractions and fractional shortening on the echocardiogram compared to mice injected with the myoblasts of wild type mice and the MSCs of mdx mice. The immunofluorescence staining of dystrophin also found much higher levels in tissue treated with $\mathrm{MB}^{\mathrm{wt}} / \mathrm{MB}^{\mathrm{mdx}}$ fusion cells compared to $\mathrm{MB}^{\mathrm{wt}} / \mathrm{MSC}^{\mathrm{wt}}$. Geng et al. ${ }^{*}$ [26] also demonstrated that differentiation was essential. Although MSCs induced toward myogenic differentiation failed to improve muscle function despite expressing myostatin on immunofluorescence and RT-PCR, MSCs that were subsequently treated with myostatin antibodies had greatly improved muscle function. This suggests that the benefits of MSCs are not directly from their differentiation but rather from their ability to induce differentiation in tissue, which benefits from the presence of myostatin antibodies. Through cell culture, Geng et al.* [26] showed that increased myostatin antibody concentration is associated with decreased MSC differentiation into adipocytes on cell culture and increased myogenesis with increased MyoD expression on RT-PCR. Pang et al. [21] found both ELSCs and MSCs were able to provide significant benefits. ELSCs outperformance of MSCs was attributed to the increased differentiation potential of ELSCs, as evidenced by more MHC and myogenin expression on cultures. Valadares et al. [22] experimented with various sources of pericytes and found that only 
adipose-derived pericytes increased the life expectancy of the DMD mice. They also analyzed transcript and protein expression and demonstrated the low myogenic potential of pericytes. In Siemionow et al. (2021)* [24], the skeletal myosin heavy chain expression in differentiated myoblasts was significantly higher than in undifferentiated myoblasts. The differentiation of MSCs down myogenic lineages is highly controversial, and although some of the included studies show myogenic-like differentiation, there is a possibility of it being an artifact due to the contamination of MSC cultures with myogenic cells.

3.6.3. MSC Incorporation and Proliferation in Muscle Is Correlated with Improved Outcomes

Six studies (Siemionow et al. (2019)* [20], Valadares et al. [22], Siemionow et al. $(2021)^{*}$ [24], Nitahara-Kashara et al. * [25], Ruehle et al.* [28], Rousseau et al. [29]) showed that stem cell incorporation and proliferation in muscle tissue was essential. The fused cells used by Siemionow et al. (2019) [20] demonstrated significant improvement in cardiac function. Echocardiography and histological analysis showed less fibrosis than saline or treatment with non-fused cells. These findings were attributed to fused cells having better engraftment potential and lower levels of rejection. Ruehle et al. [28] found that single-cell MSCs failed to improve the isometric torque of the ankle plantar flexor muscles via servomotor and could not be reliably identified on histology at any point during the experiment. Aggregated MSCs were able to improve muscle function and could be detected on histology for up to 7 days in cardiotoxin-injured wild type muscle and up to 3 days in mdx muscle. Aggregated MSCs also had higher levels of growth factors (IL-6, PGE-2, and HGF) on ELISAs, which would facilitate proliferation. Valadares et al. [22] failed to find any transplanted human cells in the mice gastrocnemius on histology and also failed to find any improvements in function as well. Rousseau et al. [29] found mdx mice transplanted with $10 \mathrm{~J}$ mesenchymal progenitor cells (MPCs) had increased protection against eccentric contractions. That group was the only one in the study that had increased dystrophin positive fibers on immunohistochemistry due to the fusion of donor MPCs and host muscle fibers. Siemionow et al. (2021) [24] demonstrated that fusing myoblasts with MSCs significantly increased both dystrophin and skeletal myosin heavy chain expression in vivo compared to injecting unfused cells. The increase is likely due to a synergistic effect of the increased differentiation of the myoblasts and the higher proliferation potential of the MSCs. Nitahara-Kashara et al.* [25] found that IL-10 expressing MSCs had significantly more cell survival and were more effective at enhancing post-transplantation retention compared to controls in their mice models. While muscle function was not measured in mice, the canine models they used also demonstrated higher retention of IL-10 MSCs in muscles with improvements in motor function.

\subsubsection{Improved Exercise Resistance as a Major Mechanism of MSC's Benefits}

Nitahara-Kashara et al.* [25] noted that while they found that both hDPSC and IL-10hDPSC-treated CXMD J exhibited no significant difference in running speed, dogs treated with IL-10-hDPSC exhibited significantly higher torque values, lower CK \& lactic acid levels post-exercise, and higher muscle mass than untreated and normal hDPSC groups. As the $C X M D_{J}$ were sacrificed after 8 weeks of treatment, further investigation is necessary to determine if IL-10-hDPSC would maintain running speed longer than regular hDPSC due to the evidence of improved exercise resistance.

On a related note, Rousseau et al. [29] found no significant force difference between any of the groups they tested. Mdx mice with $10 \mathrm{~J} \mathrm{MPCs}$ transplanted were found to have increased muscle protection against eccentric contractions through their eccentric contraction protocol, but no improvements in the performance of their isometric contraction protocol were observed. Immunohistochemistry was able to detect significantly higher levels of dystrophin in mdx mice transplanted with $10 \mathrm{~J}$ MPCs compared to any other groups, suggesting that replacing dystrophin increases resistance to exercise and contraction-induced injury but not the strength of the muscle. They unfortunately did not measure cardiac function, which if improved would provide strong evidence for dys- 
trophin being protective against contraction-induced injury, as the heart is most likely to sustain eccentric damage during normal activity.

\section{Discussion}

Despite DMD being first described in the 1860s, little was known about the pathophysiology of the disease until the late 1980s, and even now, corticosteroids are the most common method of treatment that provides symptomatic control and attempts to slow progression without directly addressing the root cause of DMD—a lack of dystrophin [32]. Finding an effective treatment to improve quality of life and life expectancy would provide immense benefits to patients and society at large. MSC-based therapies provide attractive therapeutic options due to their relative abundance and ability to mitigate inflammationthe main driver of fibrosis and loss of muscle function in patients-directly and through its immunomodulatory effects [33]. Through this study, we consolidated all studies evaluating the effectiveness of MSCs in treating DMD. We found that modifying MSCs to promote differentiation and proliferation are likely to improve the effectiveness of MSC treatment. Our study also highlights the necessity for standardized protocols and further studies on which modifications are most effective to maximize the therapeutic potential of MSCs.

We found that the most common issue with transplanted naïve MSCs was that they have short-term survival in vivo, as evidenced by several studies (Valadres et al. [22], Nitahara-Kashara et al. [25], Ruehle et al. [28]) failing to find immigrated MSCs in host tissue. Furthermore, many of the studies only investigate local injections of MSCs (Esper et al. [23], Siemionow et al. (2021) [24], Nitahara-Kashara et al. [25], Ruehle et al. [28], Rousseau et al. [29]). However, due to the systemic nature of DMD, a systemic delivery method is needed, and thus the optimal method of ensuring MSC incorporation is unclear. Based on our study, modifying MSCs to promote differentiation (i.e., fused cells), aggregation (i.e., aggregated MSCs), or proliferation (i.e., myostatin antibodies) tended to yield better outcomes and was more likely to result in direct improvements in muscle functions and not just in the markers of muscle function such as creatine kinase. Also of note is that none of the included studies worked with skeletal muscle resident MSCs. Bone marrow MSCs were predominantly used, which could be a potential source of weak results in some studies.

The exact mechanism of MSCs improving muscle function is not clear either. MSCs could differentiate myogenically or augment myogenic cell's abilities to regenerate. The selected studies had some evidence of both hypotheses, and future studies will hopefully establish the pathways involved that would have significant implications for MSC modification.

Two studies (Siemionow et al. (2019) [20], Valadares et al. [22]) failed to show benefits in skeletal muscle function but found a longer life expectancy in mdx mice treated with MSCs. While those studies did not directly address the reason for the longer life expectancy, MSCs have been shown to reduce cellular senescence in premature mice. Rousseau et al. found that MSCs improved resistance to contraction-induced injury, which would theoretically improve life expectancy but was unfortunately not measured.

This review was limited by the wide range of protocols used by the included studies. MSCs were harvested, processed, and delivered differently in each study. For example, some delivered MSCs systemically, others with local injections, and one even administered MSCs intraperitoneally. Modified MSCs were only modified in one manner, and there was essentially no overlap and comparison in the modifications between studies. These differences make direct comparisons between the studies challenging and prevents us from studying the relative effectiveness of different modifications. Therefore, we are unable to make solid and generalizable claims about the efficacy of different methods. Most of these experiments were performed in animal models, and human trials are still very rare, as evidenced by only one human study in our analysis. Whether these findings are transferable to humans requires further investigation. 
Future studies should focus on direct comparisons of various modifications or different combinations of them to optimize the use of MSCs. Creating a standardized protocol for the harvesting, processing, and delivery of MSCs would also be helpful to allow for more direct comparisons between studies. Furthermore, comparing different cell sources and cell numbers to maximize MSC effects in treatment is necessary as well. More human trials should be attempted to ensure that results from animal models are transferable to clinical practice. According to ClinicalTrials.gov, there are only three clinical trials investigating the use of MSCs in DMD, with no results released. This demonstrates the urgent need for new developments in therapeutics.

Our study establishes that MSCs have therapeutic potential in DMD. Modified MSCs apparently provide more benefits than naïve MSCs, although which modifications are optimal have yet to be confirmed. We have identified three characteristics of modified MSCs that have been associated with better outcomes, namely, increased myogenic differentiation, aggregation in the target tissue, and proliferation potential. Using highly optimized MSCs to treat DMD could revolutionize treatment — which is largely palliative-for the most common cause of muscular dystrophy and could provide the groundwork for treating other muscular dystrophies using MSCs.

Supplementary Materials: The following are available online at https://www.mdpi.com/article/10 $.3390 /$ biomedicines $9091097 /$ s1.

Author Contributions: O.Y.-J.S. performed the systematic research, analyzed data, and wrote the manuscript. Y.-F.C. and H.-T.X. edited the manuscript. C.-W.L. designed and supervised the study. All authors have read and agreed to the published version of the manuscript.

Funding: This research was funded by Hong Kong Government Research Grant Council, General Research Fund (Grant number 14104620 to C.-W.L.). And The APC was funded by Hong Kong Government Research Grant Council, General Research Fund (Grant number 14104620 to C.-W.L.).

Institutional Review Board Statement: Not applicable.

Informed Consent Statement: Not applicable.

Data Availability Statement: Not applicable.

Acknowledgments: This work was supported by the Hong Kong Government Research Grant.

Conflicts of Interest: All authors declare that they have no conflict of interest.

\section{References}

1. Laing, N.G.; Davis, M.R.; Bayley, K.; Fletcher, S.; Wilton, S.D. Molecular diagnosis of duchenne muscular dystrophy: Past, present and future in relation to implementing therapies. Clin. Biochem. Rev. 2011, 32, 129. [PubMed]

2. Allen, D.G.; Whitehead, N.P.; Froehner, S.C. Absence of dystrophin disrupts skeletal muscle signaling: Roles of $\mathrm{Ca}^{2+}$, reactive oxygen species, and nitric oxide in the development of muscular dystrophy. Physiol. Rev. 2016, 96, 253-305. [CrossRef] [PubMed]

3. Romitti, P.; Puzhankara, S.; Mathews, K.; Zamba, G.; Cunniff, C.; Andrews, J.; Matthews, D.; James, K.; Miller, L.; Druschel, C.; et al. Prevalence of Duchenne/Becker muscular dystrophy among males aged 5-24 years-four states, 2007. Morb. Mortal. Wkly. Rep. 2009, 58, 1119-1122.

4. Naidoo, M.; Anthony, K. Dystrophin Dp71 and the neuropathophysiology of Duchenne muscular dystrophy. Mol. Neurobiol. 2020, 57, 1748-1767. [CrossRef] [PubMed]

5. Landfeldt, E.; Lindgren, P.; Bell, C.F.; Schmitt, C.; Guglieri, M.; Straub, V.; Lochmüller, H.; Bushby, K. The burden of Duchenne muscular dystrophy: An international, cross-sectional study. Neurology 2014, 83, 529-536. [CrossRef]

6. Passamano, L.; Taglia, A.; Palladino, A.; Viggiano, E.; D'Ambrosio, P.A.; Scutifero, M.; Cecio, M.R.; Torre, V.; De Luca, F.; Picillo, E.; et al. Improvement of survival in Duchenne Muscular Dystrophy: Retrospective analysis of 835 patients. Acta Myol. 2012, 31, 121.

7. BEYTÍA, M.D.; Vry, J.; Kirschner, J. Drug treatment of Duchenne muscular dystrophy: Available evidence and perspectives. Acta Myol. 2012, 31, 4 .

8. Sienkiewicz, D.; Kulak, W.; Okurowska-Zawada, B.; Paszko-Patej, G.; Kawnik, K. Duchenne muscular dystrophy: Current cell therapies. Ther. Adv. Neurol. Disord. 2015, 8, 166-177. [CrossRef]

9. Sanzarello, I.; Merlini, L.; Traina, F.; Rosa, M.A.; Faldini, C. Corticosteroid treatment impact on spinal deformity in Duchenne Muscular Dystrophy. Int. Sch. Res. Notices 2014, 2014, 965235. [CrossRef] [PubMed]

10. Moghadam-Kia, S.; Werth, V.P. Prevention and treatment of systemic glucocorticoid side effects. Int. J. Dermatol. 2010, 49, 239-248. [CrossRef] [PubMed] 
11. Rybalka, E.; Timpani, C.A.; Debruin, D.A.; Bagaric, R.M.; Campelj, D.G.; Hayes, A. The failed clinical story of myostatin inhibitors against Duchenne muscular dystrophy: Exploring the biology behind the battle. Cells 2020, 9, 2657. [CrossRef]

12. Klingler, W.; Jurkat-Rott, K.; Lehmann-Horn, F.; Schleip, R. The role of fibrosis in Duchenne muscular dystrophy. Acta Myol. 2012, 31,184 .

13. Dzierlega, K.; Yokota, T. Optimization of antisense-mediated exon skipping for Duchenne muscular dystrophy. Gene Ther. 2020, 27, 407-416. [CrossRef]

14. Echevarría, L.; Aupy, P.; Goyenvalle, A. Exon-skipping advances for Duchenne muscular dystrophy. Hum. Mol. Genet. 2018, 27, R163-R172. [CrossRef]

15. Sheikh, O.; Yokota, T. Developing DMD therapeutics: A review of the effectiveness of small molecules, stop-codon readthrough, dystrophin gene replacement, and exon-skipping therapies. Expert Opin. Investig. Drugs 2021, 30, 167-176. [CrossRef]

16. Maffioletti, S.M.; Noviello, M.; English, K.; Tedesco, F.S. Stem cell transplantation for muscular dystrophy: The challenge of immune response. BioMed Res. Int. 2014, 2014, 964010. [CrossRef] [PubMed]

17. Musiał-Wysocka, A.; Kot, M.; Majka, M. The pros and cons of mesenchymal stem cell-based therapies. Cell Transplant. 2019, 28, 801-812. [CrossRef] [PubMed]

18. Slim, K.; Nini, E.; Forestier, D.; Kwiatkowski, F.; Panis, Y.; Chipponi, J. Methodological index for non-randomized studies (MINORS): Development and validation of a new instrument. ANZ J. Surg. 2003, 73, 712-716. [CrossRef]

19. Dai, A.; Baspinar, O.; Yeşilyurt, A.; Sun, E.; Aydemir, Çİ.; Öztel, O.N.; Capkan, D.U.; Pinarli, F.; Agar, A.; Karaöz, E. Efficacy of stem cell therapy in ambulatory and nonambulatory children with Duchenne muscular dystrophy-Phase I-II. Degener. Neurol. Neuromuscul. Dis. 2018, 8, 63. [CrossRef] [PubMed]

20. Siemionow, M.; Malik, M.; Langa, P.; Cwykiel, J.; Brodowska, S.; Heydemann, A. Cardiac protection after systemic transplant of dystrophin expressing chimeric (DEC) cells to the mdx mouse model of Duchenne muscular dystrophy. Stem Cell Rev. Rep. 2019, 15, 827-841. [CrossRef] [PubMed]

21. Pang, R.Q.; He, J.; Zhang, Y.Y.; Xiong, F.; Ruan, G.P.; Zhu, X.Q.; Wang, Q.; Wang, J.X.; Zhu, G.X.; Zhao, J.; et al. Systemic delivery of human bone marrow embryonic-like stem cells improves motor function of severely affected dystrophin/utrophin-deficient mice. Cytotherapy 2014, 16, 1739-1749. [CrossRef] [PubMed]

22. Valadares, M.C.; Gomes, J.P.; Castello, G.; Assoni, A.; Pellati, M.; Bueno, C.; Corselli, M.; Silva, H.; Bartolini, P.; Vainzof, M.; et al. Human adipose tissue derived pericytes increase life span in Utrn tm1Ked Dmd mdx/J mice. Stem Cell Rev. Rep. 2014, 10, 830-840. [CrossRef] [PubMed]

23. Esper, G.V.; Pignatari, G.C.; Rodrigues, M.N.; Bertagnon, H.G.; Fernandes, I.R.; Nascimento, N.; Tabosa, A.M.; Beltrão-Braga, P.C.; Miglino, M.A. Aquapuncture using stem cell therapy to treat MdX mice. Evid. Based Complement. Altern. Med. 2015, 2015, 132706. [CrossRef] [PubMed]

24. Siemionow, M.; Szilagyi, E.; Cwykiel, J.; Domaszewska-Szostek, A.; Heydemann, A.; Garcia-Martinez, J.; Siemionow, K. Transplantation of Dystrophin Expressing Chimeric Human Cells of Myoblast/Mesenchymal Stem Cell Origin Improves Function in Duchenne Muscular Dystrophy Model. Stem Cells Dev. 2021, 30, 190-202. [CrossRef] [PubMed]

25. Nitahara-Kasahara, Y.; Kuraoka, M.; Oda, Y.; Hayashita-Kinoh, H.; Takeda, S.I.; Okada, T. Enhanced cell survival and therapeutic benefits of IL-10-expressing multipotent mesenchymal stromal cells for muscular dystrophy. Stem Cell Res. Ther. $2021,12,105$. [CrossRef] [PubMed]

26. Geng, J.; Peng, F.; Xiong, F.; Shang, Y.; Zhao, C.; Li, W.; Zhang, C. Inhibition of myostatin promotes myogenic differentiation of rat bone marrow-derived mesenchymal stromal cells. Cytotherapy 2009, 11, 849-863. [CrossRef] [PubMed]

27. Li, Z.; Liu, H.Y.; Lei, Q.F.; Zhang, C.; Li, S.N. Improved motor function in dko mice by intravenous transplantation of bone marrow-derived mesenchymal stromal cells. Cytotherapy 2011, 13, 69-77. [CrossRef]

28. McGreevy, J.W.; Hakim, C.H.; McIntosh, M.A.; Duan, D. Animal models of Duchenne muscular dystrophy: From basic mechanisms to gene therapy. Dis. Models Mech. 2015, 8, 195-213. [CrossRef]

29. Deconinck, A.E.; Rafael, J.A.; Skinner, J.A.; Brown, S.C.; Potter, A.C.; Metzinger, L.; Watt, D.J.; Dickson, J.G.; Tinsley, J.M.; Davies, K.E. Utrophin-dystrophin-deficient mice as a model for Duchenne muscular dystrophy. Cell 1997, 90, 717-727. [CrossRef]

30. Ruehle, M.A.; Stevens, H.Y.; Beedle, A.M.; Guldberg, R.E.; Call, J.A. Aggregate mesenchymal stem cell delivery ameliorates the regenerative niche for muscle repair. J. Tissue Eng. Regen. Med. 2018, 12, 1867-1876. [CrossRef]

31. Rousseau, J.; Dumont, N.; Lebel, C.; Quenneville, S.P.; Côté, C.H.; Frenette, J.; Tremblay, J.P. Dystrophin expression following the transplantation of normal muscle precursor cells protects $\mathrm{mdx}$ muscle from contraction-induced damage. Cell Transplant. 2010, 19, 589-596. [CrossRef] [PubMed]

32. Łoboda, A.; Dulak, J. Muscle and cardiac therapeutic strategies for Duchenne muscular dystrophy: Past, present, and future. Pharmacol. Rep. 2020, 72, 1227-1263. [CrossRef] [PubMed]

33. Han, Y.; Li, X.; Zhang, Y.; Han, Y.; Chang, F.; Ding, J. Mesenchymal stem cells for regenerative medicine. Cells 2019, 8, 886. [CrossRef] [PubMed] 